\title{
A Common Eider $\times$ King Eider Hybrid Captured on the Kent Peninsula, Nunavut
}

\author{
SARAH A. TREFRY, ${ }^{1}$ D. LYNNE DICKSON ${ }^{2}$ and ANDREA K. HOOVER ${ }^{2}$
}

(Received 11 December 2006; accepted in revised form 21 March 2007)

\begin{abstract}
On 25 June 2002, we captured and recorded measurements of a male common eider (Somateria mollissima) $\times$ king eider (S. spectabilis) hybrid at Nauyak Lake, on the Kent Peninsula, Nunavut. This is the first documented capture of a hybrid eider, rarely observed in North America. Structural body measurements and mass of the hybrid were intermediate compared to those of Pacific common eiders (S. m. v-nigrum) at the same study site and king eiders at a nearby study site during the same time of year. The plumage of the captured hybrid had characteristics of both parent species. Mate pairing on overlapping spring staging or wintering areas of common and king eiders may occasionally result in hybrid offspring.
\end{abstract}

Key words: common eider, Somateria mollissima v-nigrum, king eider, Somateria spectabilis, hybrid, body measurements, Kent Peninsula, Nunavut

RÉSUMÉ. Le 25 juin 2002, nous avons capturé un hybride composé d'un eider à duvet (Somateria mollissima) × un eider à tête grise (S. spectabilis) au lac Nauyak, dans la péninsule de Kent, au Nunavut, puis nous avons pris note de ses mesures. Il s'agit de la première capture répertoriée d'un eider hybride, ce qui est rarement observé en Amérique du Nord. Les mesures et la masse de la structure corporelle de l'hybride étaient intermédiaires comparativement à celles des eiders à duvet du Pacifique $(S$. $m$. $v$ nigrum) du même lieu d'étude et à celles des eiders à tête grise d'un lieu d'étude avoisinant pendant la même période de l'année. Le plumage de l'hybride que nous avons capturé présentait des caractéristiques des deux espèces. Il arrive parfois que les accouplements aux haltes migratoires du printemps ou aux aires d'hivernage partagées par les eiders à duvet et les eiders à tête grise donnent lieu à une progéniture hybride.

Mots clés : eider à duvet, Somateria mollissima v-nigrum, eider à tête grise, Somateria spectabilis, hybride, mesures du corps, péninsule de Kent, Nunavut

Traduit pour la revue Arctic par Nicole Giguère.

\section{INTRODUCTION}

Common eiders (Somateria mollissima) and king eiders (S. spectabilis), two members of the genus Somateria, are genetically very close (Livezey, 1995; Kerr et al., 2007). The presence of common $\times$ king eider hybrids may reflect this relatedness. The overlap of wintering ranges in the Bering Sea (Kistchinski, 1973) and spring staging areas in the southeastern Beaufort Sea (Alexander et al., 1997), as well as genetic closeness, may contribute to interspecies pairing, as mate pairing for both king eiders and common eiders is thought to occur on the wintering or spring staging grounds (Goudie et al., 2000; Suydam, 2000).

While hybrids of common and king eiders are known to occur (Pettingill, 1959, 1962; Palmer, 1976; Greig, 1989; DeVink et al., 2003), sightings are rare in North America, and only males have been detected and described (Goudie et al., 2000). It is certainly possible that female hybrids exist, but they may go undetected partly because of plumage similarities with their parent species (Pettingill, 1959). In this note we describe a male hybrid that was captured, measured, and photographed in Nunavut, Canada.

\section{METHODS}

From 2001 to 2004, Pacific common eiders (S. m. vnigrum) were trapped and banded at Nauyak Lake, Nunavut, approximately $145 \mathrm{~km}$ southwest of Cambridge Bay on the Kent Peninsula $\left(68^{\circ} 21^{\prime} \mathrm{N}, 107^{\circ} 41^{\prime} \mathrm{W}\right)$ during the second half of June. Occasionally other species were caught in the nets, including king eiders and long-tailed ducks (Clangula hyemalis). On 25 June 2002, we caught what appeared to be a male common $\times$ king eider hybrid. The bird was flying towards the breeding colony with a pair of king eiders. This was the first identifiable hybrid from 266 male common eiders captured at Nauyak Lake during the summers of 2001 to 2004. In addition, during the third week of June in 2003 and 2004, we caught 15 male king eiders in the Kagloryuak River valley, Victoria Island, Northwest Territories $\left(70^{\circ} 21^{\prime} \mathrm{N}, 110^{\circ} 30^{\prime} \mathrm{W}\right)$, about $250 \mathrm{~km}$ north of our banding site on the Kent Peninsula. We banded and weighed all birds captured from both sites and took tarsus, wing, and head measurements (Table 1; Mendall, 1980, 1986; Dzubin and Cooch, 1992).

\footnotetext{
${ }^{1}$ Department of Biological Sciences, University of Alberta, Edmonton, Alberta T6G 2E9, Canada; strefry@ ualberta.ca

${ }^{2}$ Canadian Wildlife Service, \# 200, 4999-98 Ave., Edmonton, Alberta T6B 2X3, Canada

(C) The Arctic Institute of North America
} 
TABLE 1 . Body mass $(\mathrm{g})$ and morphological measurements $(\mathrm{mm})$ of a male common eider (Somateria mollissima) $\times$ king eider $($ S spectabilis) hybrid captured at Nauyak Lake, on the Kent Peninsula, Nunavut, compared to measurements of male parent species also captured at Nauyak Lake (common eiders) or at the Kagloryuak River valley on Victoria Island, Northwest Territories (king eiders). Data are presented as mean \pm SD, ranges in parentheses, and sample size. Body and head measurements were taken as described by Dzubin and Cooch (1992), and bill measurements, as described by Mendall (1980, 1986).

\begin{tabular}{|c|c|c|c|c|c|c|c|}
\hline Species & Body Mass & Tarsus Bone ${ }^{1}$ & Flat Wing ${ }^{2}$ & $\begin{array}{l}\text { Head } \\
\text { Length }^{3}\end{array}$ & $\begin{array}{l}\text { Total Bill } \\
\text { Length }^{4}\end{array}$ & $\begin{array}{l}\text { Culmen } \\
\text { Midline }^{5}\end{array}$ & $\begin{array}{l}\text { Nostril } \\
\text { Extension }\end{array}$ \\
\hline Common $\times$ king eider hybrid & 1950 & 49.0 & 291.0 & 120.3 & 66.0 & 36.6 & 32.8 \\
\hline King eiders & $\begin{array}{c}1616 \pm 192.8 \\
(1420-1875) \\
n=14\end{array}$ & $\begin{array}{c}48.0 \pm 1.9 \\
(45.2-52.1) \\
\mathrm{n}=15\end{array}$ & $\begin{array}{c}277.1 \pm 7.5 \\
(257-285) \\
n=14\end{array}$ & $\begin{array}{c}111.3 \pm 2.1 \\
(107.6-115.2) \\
\mathrm{n}=15\end{array}$ & & $\begin{array}{c}31.4 \pm 2.2 \\
(28.5-37.4) \\
\mathrm{n}=15\end{array}$ & \\
\hline Common eiders & $\begin{array}{c}2426.1 \pm 198.2 \\
(1750-3100) \\
n=259\end{array}$ & $\begin{array}{c}54.9 \pm 2.9 \\
(40.2-65.7) \\
\mathrm{n}=259\end{array}$ & $\begin{array}{c}312.3 \pm 9.1 \\
(286-380) \\
n=259\end{array}$ & $\begin{array}{c}132.7 \pm 4.3 \\
(119.8-145.4) \\
\mathrm{n}=259\end{array}$ & $\begin{array}{c}74.0 \pm 3.5 \\
(63.9-84.3) \\
n=265\end{array}$ & $\begin{array}{c}52.2 \pm 3.5 \\
(36.6-72.8) \\
\mathrm{n}=259\end{array}$ & $\begin{array}{c}37.7 \pm 3.2 \\
(29.6-63.8) \\
\mathrm{n}=259\end{array}$ \\
\hline
\end{tabular}

${ }^{1}$ The diagonal length of the tarsometatarsus bone only.

${ }^{2}$ Maximum measurement from the bend of the closed wing to the longest primary, with the wing flattened and the primary straightened.

${ }^{3}$ The length of the skull from the external occipital ridge (at the back of the head) to the distal tip of the bill nail.

${ }^{4}$ From tip of bill to posterior end of frontal lobe; referred to by Dzubin and Cooch (1992) as Culmen 2.

${ }^{5}$ From anterior end of feathering on top of middle of bill to the tip of the bill; referred to by Dzubin and Cooch (1992) as Culmen 1.

${ }^{6}$ From posterior end of nasal opening to posterior end of frontal lobe.

\section{RESULTS AND DISCUSSION}

The hybrid (Fig. 1) exhibited plumage traits of both a common eider (Fig. 2) and a king eider (Fig. 3). The upper back and neck were white in a pattern resembling both parent species, but the mantle and tertials were grey, rather than black (as in the king eider) or white (as in the common eider). As in both parent species, the undertail, tail, and rump were black except for the typical white flank patch. The wing coverts were white and the primaries and secondaries black, as in a common eider.

The head revealed the clearest blending of traits of both species. The crown and nape were pale blue-grey, as in a king eider. The black feathers edging the culmen process had a V-pattern like that of a king eider, and the green wash under the eye resembled the king eider pattern. This coloration is more accurately depicted in Figure 4 than in Figure 1, in which the angle makes this green appear quite dark. Black surrounding the eye was perhaps a partial retention of the black cap of the common eider. The bill was orange, as in a common eider, without the red seen in king eiders. The bill shape was more bulbous than in a Pacific common eider, but not as large or protruding as a king eider culmen process. In side profile, the hybrid's head shape seemed intermediate between the two parent species, the common eider tending to be more rounded and the king eider more angular (Fig. 4).

Mean measurements of king eiders were smaller than those of common eiders although there was some overlap in the ranges (Table 1). Body measurements of the captured hybrid generally appear to fall towards the upper end of the king eider range and the lower end of a common eider range, indicating a body size and structure intermediate to those of the two parent species.
Several observations of other individuals on the Nauyak Lake common eider colony suggested potential breeding between common and king eiders. In late June 2003, we observed an eider pair consisting of a male king eider and a female common eider. In 2004, a male king eider was observed on the colony, but it did not appear to have a mate. And in 2005, an unbanded eider very similar to our captured hybrid male was observed for approximately half an hour from a blind on the colony.

Other observers have also noted common and king eiders paired together on common eider breeding colonies. Pettingill (1959) reported a male king eider mated with a female common eider in Iceland. The breeding island was outside of the normal king eider breeding range, indicating that the male king eider had followed his common eider mate to her colony after pairing. Pettingill (1962) also reported a hybrid that mated with a female common eider in Iceland. Palmer (1977) documented trio-bonds of male common and king eiders paired with a female common eider in Aethey, Iceland, in 1973 and also documented male king eiders sitting near their female common eider mates while they incubated in Myrar, Iceland, in 1972. No male common eider is known to have paired with a female king eider (Palmer, 1973). Although this may happen, it would likely go undetected because king eiders tend to nest in a widely dispersed manner in remote areas.

Interspecific hybridization is quite prevalent in at least some species of waterfowl, but it is rare among sea ducks (Johnsgard, 1960; Goudie et al., 2000; Callaghan and Harshman, 2005). In some instances, such as the mallard (Anas platyrhynchos) $\times$ American black duck (Anas rubripes) complex, hybridization leads to fertile offspring (Johnsgard, 1967; Kirby et al., 2004; Mank et al., 2004); however, pairings between common and king eiders 


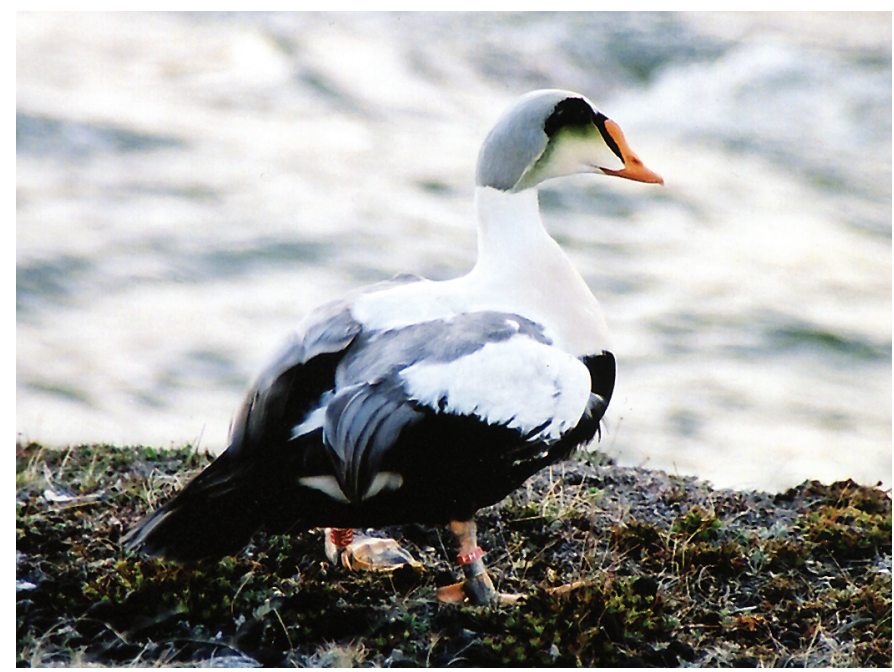

FIG. 1. Common eider (Somateria mollissima v-nigrum) $\times$ king eider (S. spectabilis) hybrid captured on the Kent Peninsula, Nunavut, on 25 June 2002. Photo: Sarah Trefry.

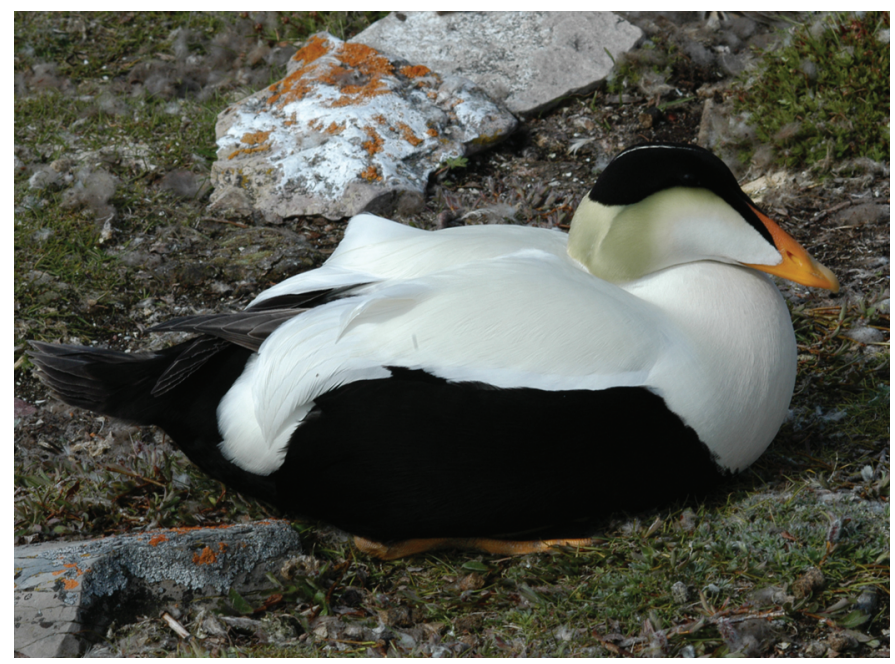

FIG. 2. Male common eider (Somateria mollissima v-nigrum), Kent Peninsula, Nunavut. Photo: Lynne Dickson.

appear to produce sterile offspring (Pettingill, 1959, 1962; Goudie et al., 2000). In a recent DNA barcoding analysis of North American birds, Kerr et al. (2007) determined that common and king eiders had overlapping barcode clusters, with $99.7 \%$ similarity in mitochondrial DNA. Although common and king eiders are similar, species distinctness is likely maintained because the F1 offspring of common and king eider pairings are infertile (Pettingill, 1959, 1962; Goudie et al., 2000).

Hybridization between common and king eiders does seem to occur where breeding ranges of the two species overlap (Palmer, 1976; DeVink et al., 2003, this study), and it has been observed in at least one instance where they do not (Pettingill, 1959), which suggests pairing on overlapping spring staging or wintering areas (Gabrielson and Lincoln, 1973; Kistchinski, 1973; Alexander et al., 1997). Hybridization may occur more frequently than previously thought, given that female hybrids are likely unnoticed

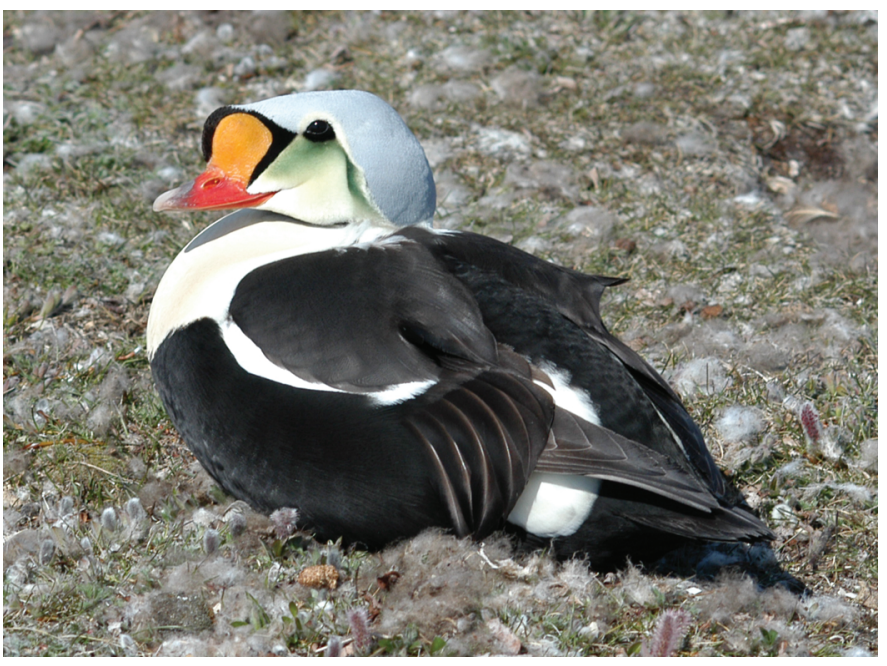

FIG. 3. Male king eider (Somateria spectabilis), Kent Peninsula, Nunavut. Photo: Lynne Dickson.

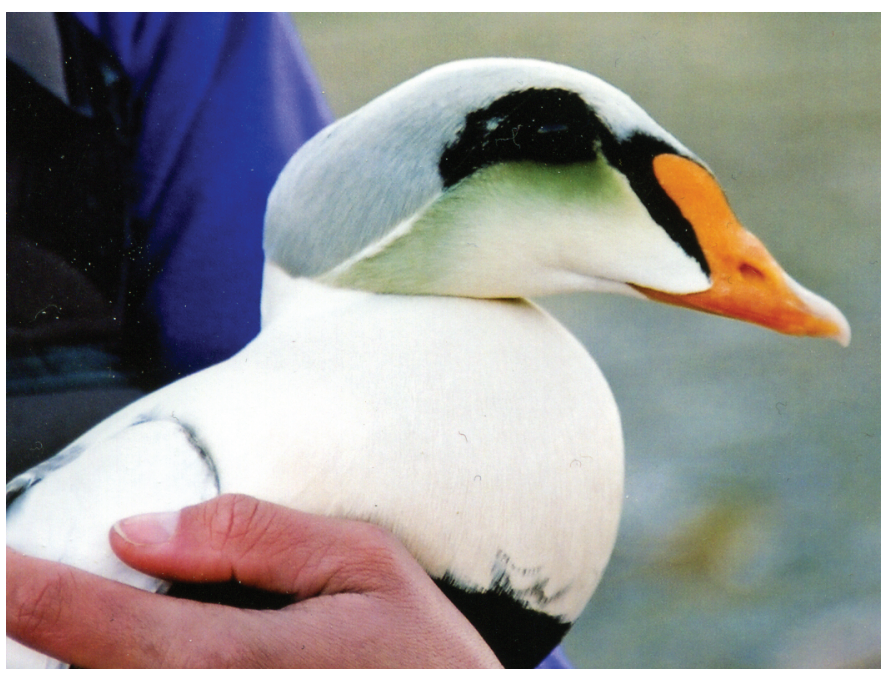

FIG. 4. Side profile of common eider (Somateria mollissima v-nigrum) $\times$ king eider (S. spectabilis) hybrid captured on the Kent Peninsula, Nunavut, on 25 June 2002. Photo: Sarah Trefry.

and that the probability of encountering paired female king eiders at nest sites is low. After pair formation in wintering and spring staging areas common to both species, male king eiders may occasionally follow female common eiders to their nesting colonies, resulting in the subsequent hybrid offspring.

\section{ACKNOWLEDGEMENTS}

Funding was provided by the Canadian Wildlife Service, the Nunavut Wildlife Management Board, the Polar Continental Shelf Project, the Sea Duck Joint Venture, the United States Fish and Wildlife Service, and the Inuvialuit Wildlife Management Advisory Council. Helen Trefry, Geoffrey Holroyd, Grant Gilchrist, Greg Robertson, Austin Reed, and three anonymous reviewers provided very useful comments on earlier drafts of this manuscript. 


\section{REFERENCES}

ALEXANDER, S.A., DICKSON, D.L., and WESTOVER, S.E. 1997. Spring migration of eiders and other waterbirds in offshore areas of the Western Arctic. In: Dickson, D.L., ed. King and common eiders of the western Canadian Arctic. Canadian Wildlife Service Occasional Paper 94. Ottawa: Environment Canada, Canadian Wildlife Service. 6-20.

CALLAGHAN, D.A., and HARSHMAN, J. 2005. Taxonomy and systematics. In: Kear, J., ed. Ducks, geese and swans. Oxford: Oxford University Press. 17.

DeVINK, J., ALLARD, K., and GILCHRIST, H.G. 2003. A male common eider $\times$ king eider hybrid at East Bay, Southampton Island, Nunavut. Birders Journal 12(5):202-204.

DZUBIN, A., and COOCH, E.G. 1992. Measurements of geese: General field methods. Sacramento: California Waterfowl Association. 20 p.

GABRIELSON, I., and LINCOLN, F.C. 1973. The birds of Alaska. Harrisburg, Pennsylvania: The Stackpole Company and Washington, D.C.: The Wildlife Management Institute.

GOUDIE, R.I., ROBERTSON, G.J., and REED, A. 2000. Common eider (Somateria mollissima). In: Poole, A., and Gill, F., eds. The birds of North America, No. 546. Philadelphia, Pennsylvania: The Birds of North America, Inc.

GREIG, K.M. 1989. Male king eider displaying to eiders. British Birds 82:446.

JOHNSGARD, P.A. 1960. Hybridization in the Anatidae and its taxonomic implications. Condor 62:25-33.

1967. Sympatry changes and hybridization incidence in mallards and black ducks. American Midland Naturalist 77: $51-63$.
KERR, K.C.R., STOECKLE, M.Y., DOVE, C.J., WEIGT, L.A., FRANCIS, C.M., and HEBERT, P.D.N. 2007. Comprehensive DNA barcode coverage of North American birds. Molecular Ecology Notes. doi:10.1111/j.1471-8286.2006.01670.x. 9 p.

KIRBY, R.E., SARGEANT, G.A., and SHUTLER, D. 2004. Haldane's rule and American black duck $\times$ mallard hybridization. Canadian Journal of Zoology 82:1827-1831.

KISTCHINSKI, A. A. 1973. Waterfowl in north-east Asia. Wildfowl $24: 88-102$.

LIVEZEY, B.C. 1995. Phylogeny and evolutionary ecology of modern seaducks (Anatidae, Mergini). Condor 97(1):233-255.

MANK, J.E., CARLSON, J.E., and BRITTINGHAM, M.C. 2004. A century of hybridization: Decreasing genetic distance between American black ducks and mallards. Conservation Genetics 5:395-403.

MENDALL, H.L. 1980. Intergradation of eastern North American common eiders. Canadian Field-Naturalist 94:286-292.

1986. Identification of eastern races of the eider. In: Reed, A., ed. Eider ducks in Canada. Occasional Report Series 47. Ottawa: Canadian Wildlife Service. 82-88.

PALMER, R.S. 1973. Icelandic eiders-a few observations. Wildfowl 24:154-157.

- 1976. Handbook of North American birds. Vol. 3. New Haven, Connecticut: Yale University Press.

- 1977. King eider studies. British Birds 70(3):107-113.

PETTINGILL, O.S., Jr. 1959. King eiders mated with common eiders in Iceland. Wilson Bulletin 71(3):205-207.

1962. A hybrid between a king eider and common eider observed in Iceland. Wilson Bulletin 74:100-101.

SUYDAM, R.S. 2000. King eider (Somateria spectabilis). In: Poole, A., and Gill, F., eds. The birds of North America, No. 491. Philadelphia, Pennsylvania: The Birds of North America, Inc. 